\title{
(LACK OF) CARE FOR STERILIZED HEALTHCARE PRODUCTS DURING TRANSPORT TO AND STORAGE IN INPATIENT UNITS ${ }^{1}$
}

\author{
Lucimara Rodrigues de Freitas², Anaclara Ferreira Veiga Tippleㄹ, Francine Vieira Pires ${ }^{4}$, Dulcelene de Sousa \\ Melo ${ }^{5}$ Jeenna Louhanna Umbelina Spagnoli ${ }^{6}$
}

\footnotetext{
${ }^{1}$ Article extracted from dissertation - The safety of processed patient care equipment during transportand storage in inpatient units, submitted to the Graduate Program in Nursing, College of Nursing, Universidade Federal de Goiás (UFG), in 2013

${ }^{2}$ M.Sc. in Nursing. Nurse, Hospital das Clínicas, UFG. Goiânia, Goiás, Brazil. E-mail: lurodriguesfreitas@yahoo.com.br

${ }^{3}$ Ph.D. in Nursing. Professor, Graduate Program in Nursing, College of Nursing, UFG. Goiânia, Goiás, Brazil. E-mail: anaclara. fen@gmail.com

${ }^{4}$ M.Sc. in Nursing. Nurse, Hospital das Clínicas, UFG. Goiânia, Goiás, Brazil. E-mail: francineyellow@gmail.com

${ }^{5}$ Ph. D. in Nursing. Professor, College of Nursing, UFG. Nurse, Hospital das Clínicas, UFG. Goiânia, Goiás, Brazil. E-mail: dsmelo11@yahoo.com.br

${ }^{6}$ Undergraduate student in Nursing, College of Nursing, UFG. Goiânia, Goiás, Brazil. E-mail: jeenna_spagnoli@hotmail.com
}

\begin{abstract}
Cross-sectional descriptive study with a quantitative approach, whose objectives were to identify those responsible for the care of sterilized healthcare products after their distribution to inpatient units, structural and material resources available for transportation and storage, and to describe the care given to transport and storage of sterilized healthcare products in inpatient units, and the occurrence of events related to these products. Data were collected by checklist in a large teaching hospital from July to September 2012, completed by direct observation and interviews with nursing managers. After descriptive analysis, none of the 11 units met all recommendations concerning the structure, material resources or work processes for the transport and storage of sterilized healthcare products. Events related revealed lack of care of the healthcare teams in the units, and consequent risk to maintaining product sterility and patient safety.
\end{abstract}

DESCRIPTORS: Materials management, Hospial. Hospital distribution systems. Sterilization. Perioperative nursing.

\section{(DES)CUIDADO COM PRODUTOS PARA SAÚDE PROCESSADOS NO TRANSPORTE E ARMAZENAMENTO EM UNIDADES DE INTERNAÇÃO}

\begin{abstract}
RESUMO: Estudo transversal, descritivo com abordagem quantitativa, cujos objetivos foram identificar os responsáveis pelos cuidados com os produtos para saúde, após a sua distribuição nas unidades de internação, e os aspectos estruturais e recursos materiais disponíveis para o seu transporte e armazenamento; descrever os cuidados dispensados com o transporte e armazenamento de produtos para saúde, nas unidades de internação e a ocorrência de eventos relacionados com esses produtos. Os dados foram coletados em um hospital de ensino de grande porte, de julho a setembro de 2012, por um check list, preenchido por observação direta e uma entrevista com os gerentes de enfermagem. Após análise descritiva, nenhuma das 11 unidades atendia a todas as recomendações referentes à estrutura, recursos materiais e processos de trabalho para o transporte e armazenamento dos produtos. Os eventos relacionados observados revelaram descuidado da equipe de saúde nas unidades e consequente risco para a manutenção da esterilidade dos produtos e segurança do usuário.
\end{abstract}

DESCRITORES: Administração de materiais no hospital. Sistemas de distribuição no hospital. Esterilização. Enfermagem perioperatória.

\section{(DES)CUIDADO CON PRODUCTOS SANITARIOS EN EL TRANSPORTE Y ALMACENAMIENTO EN UNIDADES DE HOSPITALIZACIÓN}

RESUMEN: Estudio descriptivo transversal, con abordaje cuantitativo cuyos objetivos eran identificar los responsables de los cuidados requeridos por Productos Sanitarios después de su distribución en unidades de hospitalización, y los aspectos estructurales y recursos materiales disponibles para su transporte y almacenamiento; describir cuidados entregados en el transporte y almacenamiento de Productos Sanitarios en unidades de hospitalización, eincidencia de eventos relacionados con esos productos. Los datos fueron recolectados en un hospital clínico de gran tamaño, entre julio y septiembre de 2012, a través de un checklist, llenado con observación directa y entrevistas a los gerentes de enfermería. Después de un análisis descriptivo, ninguna de las 11 unidades observó todas las recomendaciones referentes a estructura, recursos materiales y procesos de trabajo para el transporte y almacenamiento de los productos. Los eventos relacionados observados revelaron descuidos por parte del equipo de salud en unidades, y el consiguiente riesgo en la mantención de la esterilidad de productos y seguridad del usuario.

DESCRIPTORES: Administración de materiales de hospital. Sistemas de distribución en hospital. Esterilización. Enfermería perioperatoria.

Text Context Nursing, Florianópolis, 2015 Jan-Mar; 24(1): 253-62. 


\section{INTRODUCTION}

The safe use of sterilized healthcare products (SHCP) is the sole responsibility of the institution and its team, who should ensure the structural and behavioral aspects of transportation, storage and handling, which define vulnerability of contamination. ${ }^{1-2}$

Events related are environmental conditions or adverse behaviors that can damage the packaging of SHCP and result in their contamination. ${ }^{1,3-4}$ Events related are considered to be: the number of times a product is handled before use, the number of people that handle it, improper transport conditions, dropping the product, opening and reclosing the packaging, carrying the product next to the body, attaching with elastic bands or strings, and storage in tight and stacked drawers. ${ }^{3-6}$

Recently, the American Association of Perioperative Registered Nurses (AORN) ${ }^{7}$ reinforced the use of SHCP based on the environmental conditions to which they are exposed, and control of their handling, noting that these indicators, when not controlled, can lead to loss of packaging integrity and imminent risk to patients that use critical products.

Collegiate Board Resolution 15 of the Brazilian National Health Surveillance Agency (ANVISA), ${ }^{8}$ reiterates the concept that contamination of SHCP occurs due to events related, and the expiration date for use of these products must be established individually in each institution, based on care in handling, storage and control of events that may damage their packaging.

The Brazilian Association of Operating Room, Anesthetic Recovery and Material and Sterilization Center Nurses (SOBECC), ${ }^{9}$ set forth recommendations regarding the storage of SHCP in the context of the Central Sterile Supply Department (CSSD), emphasizing that products should be stored in a centralized and exclusive area, preferably with restricted movement of persons, to ensure preservation of the barrier system of packaging, sealing and security conditions against patrimonial loss.

However, discussions on this subject, mainly at the national level, have been restricted to CSSDs. Considering that contamination of SHCP is not just linked to the time elapsed since the date of sterilization, it is emphasized that responsibility for the safety of these products, including criteria in their transport, must be shared with inpatient units, where they remain stored for different periods until the moment of use.

In this context, the role of nurses is emphasized, as their training provides technical competence and ethics about processes of sterilization and management of SHCP in health care. ${ }^{10}$ It is the responsibility of management of human and material resources to ensure the safety of these products within and outside the CSSD.

Based on these considerations, the following questions were formulated: who is responsible for processed SHCP after they are distributed to hospital units; and, how are they cared for, in order to control events related during transport, storage and handling?

The diagnosis obtained by means of this study may point to indicators that guide the planning of actions and development of protocols which guarantee the safety of SHCP, and consequently, of users. In addition, this study expands discussions regarding accountability for the safety of SHCP for managers and care providers of different care units.

The aim of this study was to identify those responsible for the care of sterilized healthcare products after their distribution in inpatient units, and the structural aspects and material resources available for their transportation and storage. The authors also sought to describe the care provided to SHCP during transport to, and storage in, inpatient units, and the occurrence of events related to these products.

\section{METHODOLOGY}

This was an exploratory, cross-sectional and descriptive study with a quantitative approach, conducted in inpatient units that store and use SHCP in a large public teaching hospital in the municipality of Goiânia, in the midwestern Brazilian state of Goiás.

In 2012, the hospital had 346 beds distributed in 12 inpatient units: adult and pediatric emergency, medical clinic, surgery, pediatric, orthopedic and tropical, maternity, high-risk nursery and the medical, surgical and neonatal intensive care unit. The surgical clinic was undergoing renovations during the study period.

The study included 11 inpatient units, the nursing managers of each of these units and the 
technicians responsible for the care of SHCP during the study period. The study also included all persons who entered and handled SHCP in the storage area of the unit during the data collection period, and engaged directly in the occurrence of a event related to $\mathrm{SHCP}$.

Two instruments were used for data collection: a checklist completed by means of direct observation as regards physical structure, material resources and events related in the units' system of SHCP storage, and characteristics of the transport of SHCP between the CSSD and units. A script for interviews with nursing managers was also used, with open and closed-ended questions relating to standardized care of SHCP by the unit, as well as the physical structure and human resources available for safety in the storage and transport of these products in the inpatient units.

The instruments were constructed based on current recommendations and health standards, ${ }^{1-2,8,11-12}$ and evaluated as for comprehensiveness, clarity, form and adequacy to the research objectives by five nurses with experience in the CSSD, by means of a workshop with extensive discussion and definition of a consensus. Prior to data collection, the instruments underwent pilot testing in three units for highly complex procedures at the same hospital. Despite these units not having inpatient beds, all performed transport and had an area for storage of SHCP, and none were included in the study.

At the evaluation meeting, the need to establish a definition for the variable "excessive handling of SHCP" was considered, which was defined as when an SHCP is touched/handled in the storage area of the inpatient unit, or removed from this area, and not used in patient care. The safe number of touches for an SHCP has still not been defined; however, it is known that less handling is associated with longer maintenance of sterility. ${ }^{4-6,13}$ It was also considered that SHCP are touched four to five times during the time between removal from the autoclave until storage in the inpatient unit.

Given the inexistence of indicators for evaluating risk of contamination of SHCP from events related, it was decided to separate the events into two groups: a "serious event related", when there was definitive breaking of the primary packaging, which led to the inevitable exposure of its contents to contaminants. Serious events related also included violation of the expiration dates for each type of packaging. Although SHCP can remain sterilized after the pre-established expiration dates, ${ }^{6,13-14}$ this was the standardized way for the institution to determine that these products were adequate for use. The other conditions described in the literature were characterized as "events related."

Data were collected from July to September 2012 by a researcher and two assistants, who were prequalified and members of the Center for Study and Research on Nursing in Prevention and Control of Healthcare-Related Infections at the College of Nursing of the Federal University of Goiás. The assistants participated exclusively in the application of the checklist, carried out by two data collectors for the simultaneous observation of the storage area and transport of SHCP between the CSSD and units.

The checklist was applied three times in each unit, once during each work shift starting 10 minutes before the shift, averaging 15 hours of observation per unit for a total of 165 hours. As regards the transport of SHCP between the CSSD and units, the standardized schedules of the CSSD were followed in the three work shifts: morning, evening and night.

The interviews were scheduled in advance and performed individually in the respondents' workplaces. There were situations in which the same nurse was responsible for managing more than one unit; in these cases, considering the specificities of each unit, the interview was applied more than once.

This project is part of an anchor study approved by the Research Ethics Committee of the hospital where the study took place under protocol $n^{\circ} .167 / 2011$. Free and Informed Consent Forms were signed by the study participants at two times: before the interview, by nursing managers of the inpatient units, and after application of the checklist, by those responsible for the care of SHCP who underwent direct observation. The data from the interviews were presented descriptively using simple frequency measurements, interspersed with data from the checklist according to treatment of themes, since they were shown to enable grasping the reality investigated. 


\section{RESULTS}

In 10 units (90.9\%), critical, semi-critical and non-critical SHCP were stored in non-exclusive areas together with non-sterilized items, such as the medications room, suture and resuscitation room and storeroom for cleaning equipment and products. Table 1 shows the physical structure and resources available for storage of SHCP in the units.

Table 1 - Physical structure and material resources for the storage of sterilized healthcare products in inpatient units $(n=11)$ of a large hospital. Goiânia, Goiás, 2012

\begin{tabular}{lrr}
\hline $\begin{array}{l}\text { Physical structure and resources available } \\
\text { in the storage area }\end{array}$ & $\mathbf{n} \%$ \\
\hline $\begin{array}{l}\text { Type of area } \\
\text { Non-exclusive }\end{array}$ & 10 & 90.9 \\
$\quad$ Exclusive & 1 & 9.1 \\
$\begin{array}{l}\text { Storage Location } \\
\quad \text { Cabinet coated with Formica, closed and }\end{array}$ & 11 & 100.0 \\
attached to the wall & 3 & 27.3 \\
Closed metal cabinet & 3 & 27.3 \\
$\begin{array}{l}\text { Shelves coated with Formica, open and } \\
\text { attached to the wall }\end{array}$ & 2 & 18.2 \\
$\begin{array}{l}\text { Plastic container } \\
\text { Cardboard box }\end{array}$ & 2 & 18.2 \\
Air conditioning system & & \\
$\quad$ Non-exclusive air conditioning & 3 & 27.3 \\
Exclusive air conditioning & 1 & 9.1 \\
Inexistent & 7 & 63.6 \\
Resources and structure for hand hygiene & & \\
Yes & 9 & 81.9 \\
No & 2 & 18.2 \\
\hline & & \\
\hline
\end{tabular}

In four units (36.4\%), the SHCP were placed in cabinets attached to the wall in access corridors to the wards, where there is a large flow of people; five $(45.5 \%)$ had more than one location to store SHCP, including two (18.2\%) that stored them in cardboard boxes or plastic containers placed on benches.

The air conditioning of the storage area of three units $(27.3 \%)$ was shared between envi- ronments integrated with patient beds and the nursing station. In the unit that had exclusive air conditioning, this was maintained turned off. Seven units $(63.6 \%)$ had all the resources for hand hygiene (sink, liquid soap, paper towels and exclusive waste basket). Of these, five also had 70\% alcohol, this being the only resource in the storage area of two units (18.2\%).

The nursing managers were aware of the structure and resources available to store SHCP when they confirmed the aspects identified during observation in the interview. Two of the nursing managers $(18.2 \%)$ considered the storage conditions to be unfavorable, and cited the need for yet unplanned improvements and renovations.

Twenty-two people responsible for the care of SHCP were observed in the inpatient units during the study period: $16(72.7 \%)$ nursing technicians and six $(27.3 \%)$ fellows (nursing students). Of these, $21(95.4 \%)$ performed, in addition to the care of SHCP, other duties such as direct care of patients, sample collection and preparation of medications. According to ten managers $(90.9 \%)$, staff sizing did not permit exclusive responsibilities.

The existence of an assignment protocol for those responsible for the care of SHCP was confirmed by six managers ( $54.5 \%)$, but were unavailable in five units because they were under review.

Unrestricted access to storage areas by different members of the healthcare team and even support staff (resident physicians, nutritionists, cleaning and laundry service workers, administrative staff and warehouse and maintenance workers) was observed. In four (36.4\%) units, patients or companions in the storage area were observed handling SHCP such as gauze, swabs and bandages.

There was adherence to three conditions recommended for storage of $\mathrm{SHCP}$, two with low frequencies, shown in table 2, which includes expected safety items, present in the observation instrument and which did not have adherence.

All units controlled the entry of SHCP into the storage area, filing the duplicate form established by the CSSD, which contained the number of SHCP provided to the unit (trays, bowls, bedpans, etc.) and the number distributed per period. Specific forms of the units were also completed by six $(27.3 \%)$ staff members responsible for the care of SHCP. 
Table 2 - Care in storage of sterilized healthcare products in inpatient units, according to the number of staff members responsible for it (n=22). Goiânia, Goiás, 2012

\begin{tabular}{lrr}
\hline $\begin{array}{l}\text { Care in the storage of sterilized healthcare } \\
\text { products in inpatient units }\end{array}$ & n & $\%$ \\
\hline $\begin{array}{l}\text { Adherence } \\
\text { Control of entry of sterilized healthcare }\end{array}$ & 22 & 100.0 \\
$\begin{array}{l}\text { products } \\
\text { Availability according to identification }\end{array}$ & 6 & 27.3 \\
$\begin{array}{l}\text { Organization according to chronological order } \\
\text { Non-Adherence }\end{array}$ & 2 & 9.1 \\
$\begin{array}{l}\text { Verification of package integrity } \\
\text { Verification of absence of moisture }\end{array}$ & - & - \\
$\begin{array}{l}\text { Verification of expiration date } \\
\text { Exclusively distributed by designated }\end{array}$ & - & - \\
professional & - & - \\
$\begin{array}{l}\text { Distribution according to chronological order } \\
\text { Control of exit of sterilized healthcare }\end{array}$ & - & - \\
products & - & - \\
Cleaning of surfaces and furnishings & - & - \\
\hline
\end{tabular}

In caring for the cabinets designated for the storage of processed SHCP, scrubbing with $70 \%$ alcohol without prior cleaning was observed in one instance. The existence of routines for decontamination of cabinets was cited by seven nursing managers $(63.6 \%)$, whereas two $(18.2 \%)$ stated that this procedure was not performed systematically.

For presentation of events related (Table 3), the inpatient units were coded from 1 to 11 , and separated according to the type of service offered, considering that units that provide care to critical patients accumulate conditions favorable for the occurrence of infections, due to the susceptibility of patients and complexity of care procedures in which the use of SHCP classified as critical predominate.

Table 3 - Frequency of events related to SHCP in the storage area of inpatient units of a large hospital. Goiânia, Goiás, 2012

\begin{tabular}{|c|c|c|c|c|c|c|c|c|c|c|c|c|c|}
\hline \multirow{2}{*}{ Unit } & \multirow{2}{*}{1} & \multirow{2}{*}{2} & \multirow{2}{*}{3} & \multirow{2}{*}{4} & \multirow{2}{*}{5} & \multirow{2}{*}{$6^{*}$} & \multirow{2}{*}{$7^{*}$} & \multirow{2}{*}{$8^{*}$} & \multirow{2}{*}{$9^{*}$} & \multirow{2}{*}{$10^{*}$} & \multirow{2}{*}{$11^{*}$} & \multicolumn{2}{|c|}{ Total } \\
\hline & & & & & & & & & & & & $\mathbf{n}$ & $\%$ \\
\hline \multicolumn{14}{|l|}{ Events related } \\
\hline Handling without hand hygiene & 3 & 4 & 4 & 3 & 3 & 1 & 3 & 2 & 4 & 4 & 4 & 35 & 20.0 \\
\hline Excessive handling & 3 & 4 & 3 & 1 & 4 & 2 & 4 & 4 & 4 & 1 & 2 & 32 & 18.3 \\
\hline Carrying close to the body & 4 & 3 & 3 & 2 & 3 & - & 4 & 2 & 2 & - & 3 & 26 & 14.9 \\
\hline Falling on the floor & 2 & 2 & 2 & 2 & 1 & 4 & 3 & - & 1 & 1 & 2 & 20 & 11.4 \\
\hline Placement on contaminated surface & 1 & - & 2 & 1 & - & 2 & 2 & 2 & 2 & - & - & 12 & 6.90 \\
\hline Handling with contaminated gloves & 1 & - & 2 & - & - & - & 1 & - & 2 & - & 2 & 8 & 4.6 \\
\hline Carrying under the arms & 2 & - & 2 & - & 1 & - & - & 2 & - & 1 & - & 8 & 4.6 \\
\hline Storage under weight & - & - & 1 & - & 1 & 2 & - & 2 & - & - & - & 6 & 3.4 \\
\hline Storage in a tight drawer & 2 & - & 1 & 1 & 1 & - & 1 & - & - & - & - & 6 & 3.4 \\
\hline \multicolumn{14}{|l|}{ Serious events related } \\
\hline Opening and reclosing packaging & 5 & 1 & - & - & 1 & 3 & 3 & 1 & 1 & - & 3 & 18 & 10.3 \\
\hline Perforated packaging & - & - & - & - & - & - & 1 & - & - & 1 & - & 2 & 1.1 \\
\hline Expired product & - & - & - & - & - & 1 & - & - & - & 1 & - & 2 & 1.1 \\
\hline Total & 23 & 14 & 20 & 10 & 15 & 15 & 22 & 15 & 16 & 9 & 16 & 175 & 100 \\
\hline
\end{tabular}

* Inpatient units for advanced support and urgency and emergency care.

Most $(n=95 ; 54.3 \%)$ of the events related happened in the morning, when there was greater demand for procedures. The nursing technicians were most involved in these events, which repeated 175 times, when the events from the three work shifts in all units were summed. The highest frequency of events occurred in Unit 1, followed by Unit 7, the latter being for care of critically ill patients. The events related "handling without hand hygiene" and "excessive handling" were, respectively, the most frequent and occurred in all units.

The most frequent serious event related $(\mathrm{n}=18 ; 10.3 \%)$ was "opening and reclosing packaging," and occurred predominantly with SHCP packed in pairs, such as bowls, surgical gowns and drapes, that were opened for removal of one unit, then reclosed and returned to storage. This 
was also the most frequent serious event related in the critical care units, in which all other events were also observed. The event "perforated packaging" occurred in critical care units with a vaginal speculum and a package of bandages, both packaged in surgical grade paper.

For the event "placement on contaminated surface," the following scenarios were observed: table dirtied with blood, litter, sink for hand hygiene and preparation of medications, and the prescriptions bench. In one unit during the night shift, the presence of food (coffee and fruit) and one professional eating in the storage area were observed.

Figure 1 shows the ratio of SHCP that underwent events related. In characterizing these events, it was observed that smaller volume packages such as gauze, swabs, bandages and oxygen tubing were usually transported manually and in large quantities, leading to the event "falling to the floor," with their subsequent recovery for storage or use.

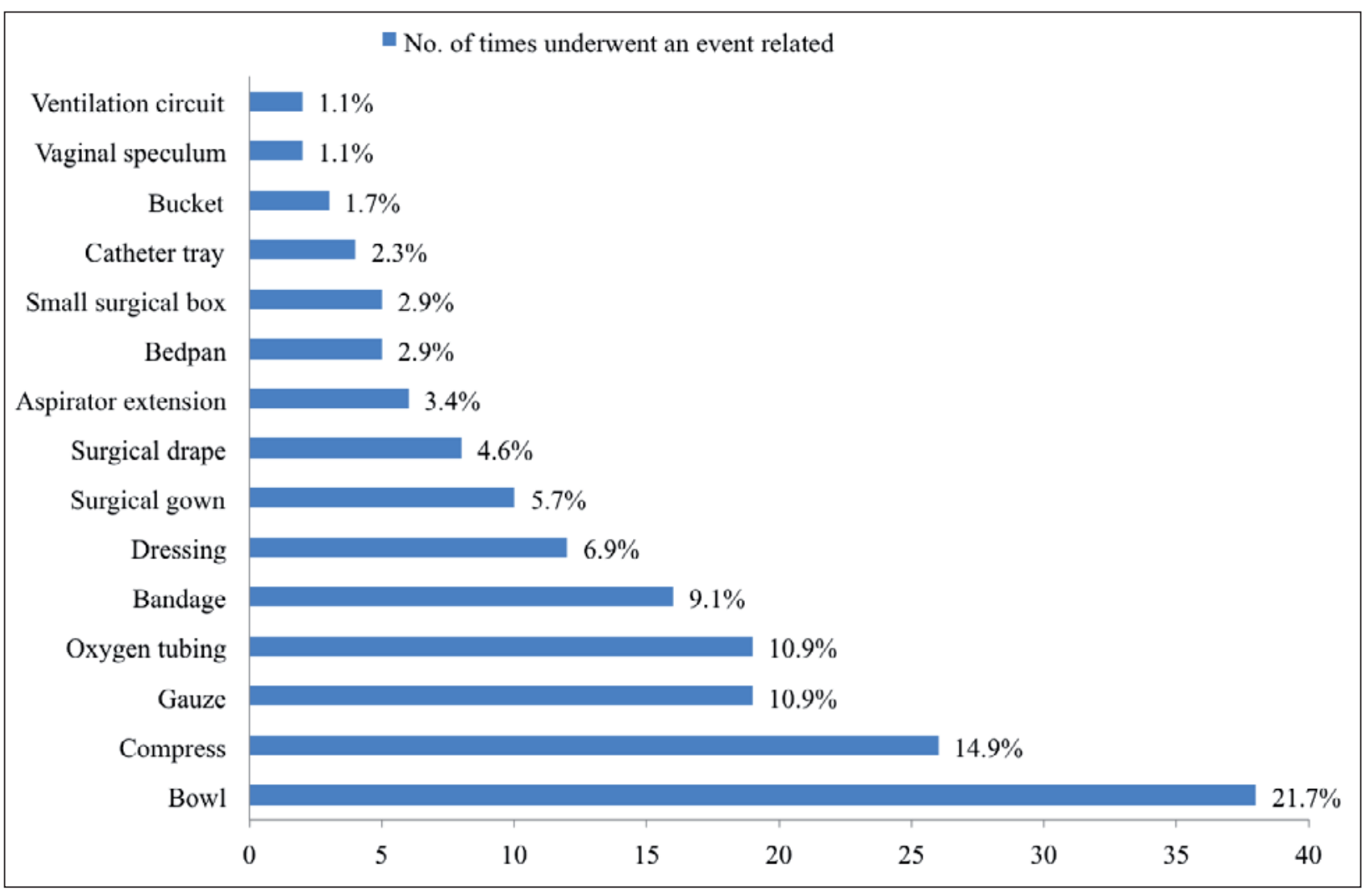

Figure 1 - Sterilized healthcare products according to the number of times they underwent events related in the storage area of inpatient units of a large hospital. Goiânia, Goiás, 2012

The transport of SHCP between the CSSD and units was carried out during the three shifts at times standardized by the CSSD, by the same 22 workers charged with the care of products, by means of open, wire carts $(\mathrm{n}=16 ; 72.7 \%)$ with uneven surfaces that pertained to these units, using a sheet or surgical drape to line the carts and cover the products. Four other professionals (18.2\%) carried the SHCP directly in their hands without sanitizing them, and two $(9.1 \%)$ carried them in plastic bags.

A cart exclusively used for transporting SHCP from the CSSD was found in one unit $(9.1 \%)$, whereas in the other units, the use of carts for transporting different inputs such as gallons of water, warehouse materials, clothes and SHCP contaminated by the presence of visible organic secretion, as noted in one unit, were observed. The routine decontamination of the carts between one transport and another was reported by nine managers $(81.8 \%)$, a procedure that was not observed during the data collection period.

\section{DISCUSSION}

In Brazil, there are no official recommendations for the storage of SHCP in inpatient units, 
although some of those applying to the CSSD can be extended to these units. It is understood that the important concepts already established, such as events related, ${ }^{1,3-7,13-14}$ should qualify this practice, modify paradigms, and direct the conduct of professionals involved, considering the structure, resources and work processes that determine the maintenance of sterility of these products. Unlike what was found in this study, which verified an absence of exclusive areas in $90.9 \%$ of inpatient units studied (Table 1), and unrestricted access to the storage area by several members of the healthcare team and support staff, including secretaries, cleaners and warehouse and maintenance workers, which may represent an additional risk to the safety of SHCP.

Restriction to the storage area does not necessarily imply a physical barrier, but mainly technical barriers that enable and induce actions by the healthcare team to maintain the safety of SHCP. It is recommended that storage of SHCP does not occur in areas of free circulation, even temporarily, and that these products are restricted to employees of the units, thus qualifying the care, ${ }^{7-9}$ different from that observed in $36.4 \%$ of the units that had storage cabinets in the hallways that were accessed by patients and caregivers.

The moment of storing and organizing SHCP in cabinets is an important opportunity to visually inspect aspects that will determine preservation of the characteristics essential for maintaining sterility, such as integrity of the packaging and sealing, absence of moisture, dirt or stains, stacking of packages and inventory turnover. ${ }^{1-}$ $4,7-9,12$ Additionally, there is the opportunity for verification, which should be done before opening the package at the time of use. However, Table 2 shows that there was no adherence to various recommended security items.

Despite all the professionals performing entry control of SHCP into the storage areas, the exit control of these products was not observed (Table 2), which does not enable their traceability, consumption statistics or even inventory control by the units, measures that would prevent shortages or unnecessary requests. ${ }^{15}$ It is understood that there are numerous challenges due to the complexity of care activities in inpatient units; however, the importance of care for SHCP cannot be underestimated, because their contamination may have direct implications for patients. In practice, it is necessary to question the sense of strictly adher- ing to an aseptic technique to perform a bandaging when the SHCP used already had perforated packaging, as was observed in this study (Table 3). Contamination of an SHCP before use in the care process mischaracterizes the act of care as careless.

Based on this premise, care in procedures involving the use of SHCP begins with the quality of sterilization, and continues in maintaining their sterility until the time of use, which justifies extending responsibility for the security of these products to the managers of the units that consume them and the professionals who use them in care procedures.

However, only two (18.2\%) managers reported discontent and the need to conform to the conditions available in the units for conditioning of SHCP. Managers have a key role in organizing the work and coordination of resources to facilitate safe and quality care. ${ }^{16}$ It is their responsibility to plan and predict, together with clinical engineering, the hospital infection control service and directives, adjustments and reforms that promote optimal conditions for storing $\mathrm{SHCP}$, emphasizing the technical and political aspects necessary for providing safe care.

The manager of the CSSD, despite developing activities and work processes specific to $\mathrm{SHCP}$ processing, can be a very important ally in the planning and implementation of security measures for the SHCP in consumer units, activities planned by the Collegiate Board Resolution. $15 .{ }^{8}$ In this study, operational partnership could be achieved by means of collaboration of nurses of the CSSD in the drafting of protocols, nonexistent in $90.9 \%$ of the units observed, and in the training of the healthcare teams of these units. Activities that, once completed, will require a plan for monitoring and supervision by the nurse manager in each unit.

Failures in the management of SHCP that begin in the CSSD and extend to inpatient units are often generated by lack of shared management. One example noted in this study was of packages of bowls, surgical gowns and drapes, which were packed in pairs, leading to the serious event related "opening and reclosing packaging." This condition represents higher risks of SHCP used in invasive procedures (surgical gowns and drapes), and occurred predominantly in care units for critical patients (Table 3). The articulation of units with the CSSD in planning unit packages of such products to meet the demands of care would solve the problem. 
"Handling without hand hygiene" was the most frequently reported event related when all such events in the inpatient units were summed; in isolation, this was the most frequent event in four units (Table 3). Although the packaging may have a biobarrier capable of protecting its contents, ${ }^{1,7-9}$ hand hygiene is a basic measure in the conservation of SHCP and in the prevention of events, because hands have the ability to harbor microorganisms and can transfer these to packaging. It is worth noting that "excessive handling" was the second most observed event (Table 3). Although not intending to defend such behavior, one can assume less risk if performed with clean hands, which reduces transient skin microbiota that contain microorganisms most frequently associated with infections. ${ }^{17-18}$

Based on the events observed in this study (Table 3), it would not make sense to establish expiration dates for SHCP tied to time (calendar/ clock) and applied universally, because the product might get infected before the time limit. This is the subject of study and discussion by several authors who support sterility control, related to undesirable or events related which may happen during transport, storage and use of SHCP. ${ }^{3-6,14,19-20}$

It is worth emphasizing that in addition to the hospital that was the study location, it is common for Brazilian healthcare institutions to work with predetermined expiration dates for type of packaging and time elapsed since sterilization, rather than to control events related. This concept may have contributed to consolidate, over the years, a false sense of safety, like a "gold standard" in packaging, for example surgical grade, conferred to the SHCP the status of inviolable, and because of this, additional care would not be necessary. Adopting the concept of events related to define the expiration date of SHCP may contribute to "awaken" professionals to safe behavior.

One recent study showed that CSSD workers identified the occurrence of events related in the storage area of this sector, even before the SHCP were distributed to consumer units (such as torn, wet packaging and overlapping sterilized packages), signaling that non-adherence of care for SHCP is not exclusively tied to the physical space where it is stored, but has an important relationship with the work processes in place. ${ }^{21}$

In the Brazilian reality, this issue has not received due attention in discussions on patient safety in health care, and it remains to be seen whether, in practice, institutions are prepared for the transformation that requires, in addition to investments in resources and structure, commitment of healthcare teams, especially nursing, to assume responsibility for articulating and managing care of SHCP in a rational and safe manner.

With regard to transport of SHCP between the CSSD and inpatient units, the literature recommends provision of proper vehicles exclusively for this use, and establishment of criteria for their sanitization, ${ }^{7-8,12}$ delegating these responsibilities to the CSSD. ${ }^{8}$ This scenario is different than what was identified in this study, in which there were situations where transport was carried out in plastic bags $(9.1 \%)$, by hand $(18.2 \%)$ and in wire carts $(72.7 \%)$ belonging to the units themselves.

Although most of the nursing managers $(81.8 \%)$ confirmed the existence of cart cleaning routines between transports, the design of the carts did not facilitate decontamination, which was not observed during the data collection period. Furthermore, only one unit $(9.1 \%)$ had a cart exclusively used for this purpose, whereas the others used the cart to transport various products, including contaminated SHCP to the CSSD, a condition that necessarily requires decontamination prior to the transport of sterilized SHCP. $1,3,9,12$

\section{CONCLUSION}

In the inpatient units investigated, those responsible for the care and storage of SHCP were members of the nursing staff, predominantly nursing technicians.

Not one storage system of the 11 inpatient units adhered to all of the recommendations on the structural aspects and material resources for the safe storage of SHCP, highlighting that the main aspect that put these products at risk of contamination was the lack of an exclusive area for storage and unrestricted access to storage areas, by favoring the occurrence of events related.

There was adherence to three conditions envisaged for the storage and conservation of SHCP in the units, two of which had low frequencies: control of entry of SHCP into the storage area; availability on shelves according to identification; and organization by chronological order. The care measures that were not adhered to were: verification of packaging integrity, absence of humidity and expiration date; distribution of SHCP by one 
professional and according to chronological order; control of exit of processed SHCP; and cleaning of surfaces and furnishings in the storage area.

The nursing staff was most involved in events related. When events from all units were summed, the events "handling without hand hygiene" and "excessive handling" predominated. Serious events related occurred predominantly in care units for critical patients, the most frequent being "opening and reclosing packaging" of SHCP packed in pairs (surgical drapes, gowns). There was no standardization of care in transporting SHCP between the CSSD and inpatient units, and the mode adopted placed these products at risk of contamination.

Given these findings, one can understand the need for changes in the management of care of $\mathrm{SHCP}$ in units that consume these inputs, in order to ensure their quality until the moment of use. However, one difficulty in realizing this study is that there were no validated indicators for assessing the conditions of storage and transportation of SHCP outside the CSSD context. In this sense, it is emphasized that the checklist created for this study enabled grasping the reality of the investigated units, and may provide support for institutions interested in performing self-assessments as to the structures and processes involved in the management of SHCP in inpatient units, which led to the current process of instrument validation.

\section{REFERENCES}

1. Association for the Advancement of Medical Instrumentation. American National Standard: comprehensive guide to steam sterilization and sterility assurance in health care facilities. ANSI/AAMI ST79:2010 \& A1:2010. Arlington (US): AAMI, 2010.

2. Rutala WA, Weber DJ. Healthcare Infection Control Practices Advisory Committee - HICPAC. Guideline for disinfection and sterilization in healthcare facilities. Atlanta (US): CDC; 2008.

3. Graziano KU, Silva A, Januncio IM. Prazo de validade de esterilização relacionado a eventos (event-related). In: Graziano KU, Silva A, Psaltikidis EM, organizadores. Enfermagem em centro de material e esterilização. São Paulo (SP): Manole; 2011. p. 237-49.

4. Young ML. Is event-related dating going away: Operating Room - OR. Manager. 2010 May; 26(5):23-5.

5. Barret R, Stevens J, Taranter J. A shelf-life trial: examining the efficacy of event related sterility principles and its implications for nursing practice. Australian J Advanced Nurs. 2003; 21(2):8-12.
6. Webster J, Lloyd W, Ho P, Burridge C, George N. Rethinking sterilization practices: evidence for event-related outdating. Infect Control Hosp Epidemiol. 2003; 24(8):622-3.

7. Association of Perioperative Registered Nurses. Perioperative standards and recommended practices: recommended practices for selection and use of packaging systems for sterilization. Denver (US): AORN; 2013.

8. Ministério da Saúde (BR). Agência Nacional de Vigilância Sanitária. Resolução n. 15 de 15 de março de 2012: Dispõe sobre requisitos de boas práticas para o processamento de produtos para saúde e dá outras providências. Brasília (DF): MS; 2012.

9. Associação Brasileira de Enfermeiros de Centro Cirúrgico. Recuperação anestésica e centro de material e esterilização: práticas recomendadas

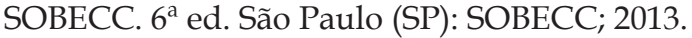

10. Conselho Federal de Enfermagem (BR). Resolução n. 424 de 19 de abril de 2012: Normatiza as atribuições dos profissionais de enfermagem em Centro de Material e Esterilização e em empresas processadoras de produtos para saúde. Brasília (DF): COFEN; 2012.

11. Sociedade Brasileira de Enfermeiros de Centro Cirúrgico. Recuperação anestésica e centro de material e esterilização: manual de práticas recomendadas pela SOBECC. $5^{\mathrm{a}}$ ed. São Paulo (SP): SOBECC; 2009.

12. Pereira MCO. Preparo, embalagem, transporte e armazenagem. In: Padoveze MC, Graziano KU, organizadores. Limpeza, desinfecção e esterilização de artigos em serviços de saúde. São Paulo (SP): APECIH; 2010. p. 83-107.

13. Jevitt D. Indefinite shelf life...amen! J Hosp Supply Processd Distrib. 1984; 2(6):36-7.

14. Klapes A, Greene VW, Langholz AC, Hunstiger C. Effect of long-term storage on sterilized status of devices in surgical packs. Infection Control. 1987; 8(7):289-92.

15. Lopes CLBC, Moraes C. Inter-relacionamento com as unidades consumidoras, fornecedoras e de apoio do Centro de Material e Esterilização. In: Graziano KU, Silva A, Psaltikidis EM, organizadores. Enfermagem em centro de material e esterilização. São Paulo (SP): Manole; 2011. p. 319-34.

16. Santos JLG, Garlet ER, Lima MADS. Revisão sistemática sobre a dimensão gerencial no trabalho do enfermeiro no âmbito hospitalar. Rev Gaúcha Enferm. 2009; 30(3):525-32.

17. World Health Organization (WHO). World alliance for safer health care. Hand hygiene in outpatient and home-based care and long-term care facilities: a guide to the application of the WHO multimodal hand hygiene improvement strategy and the "My five moments for hand hygiene". Geneva (SW): WHO Press; 2012. 
18. World Health Organization (WHO). World alliance for safer health care. Guidelines on hand hygiene in health care. First global patient safety challenge clean care is safer care. Geneva (SW): WHO Press; 2009.

19. Rutala WA, Morelli L, Weber DJ, Thomann AC. Effects of long-term storage on sterility of medical supplies. Am J Infect Control. 2006; 34(4):248.

20. Moriya GAA, Souza RQ, Pinto FMG, Graziano KU. Periodic sterility assessment of materials stored for up to 6 months at continuous microbial contamination risk: laboratory study. Am J Infect Control. 2012; 40(10):1013-5.

21. Ouriques CM, Machado ME. Enfermagem no processo de esterilização de materiais. Texto Contexto Enferm [online]. 2013 [acesso 2014 Jun 13]; 22(3):695-703. Disponível em: http://www. scielo.br/scielo.php?script=sci_arttext\&pid=S010407072013000300016\&lng=pt 